\title{
Media Spectacle and the "Massacre at Virginia Tech"
}

\author{
Douglas Kellner
}

The mainstream corporate media today process events, news, and information in the form of media spectacle. [2] In an arena of intense competition with $24 / 7$ cable TV networks, talk radio, Internet sites and blogs, and ever proliferating new media like Facebook, MySpace, and YouTube, competition for attention is ever more intense leading the media to go to sensationalistic tabloidized stories which they construct in the forms of media spectacle that attempt to attract maximum audiences for as much time as possible.

The 1990s saw the emergence and proliferation of cable news networks, talk radio, and the Internet, and megaspectacles of the era included the O.J. Simpson murder trials, the Clinton Sex scandals and impeachment, and on a global level the life and death of princess Diana. The era also saw an intensification of celebrity news and scandals, with Michael Jackson perhaps the most sensational case (see Kellner 2003a).

The new millennium opened with a hung 2001 presidential election between Al Gore and George W. Bush, and a 36 day Battle for the White House and frenzied media spectacle, resulting in a 5-4 Supreme Court decision for Bush that blocked the counting of votes in Florida and generated one of the most momentous political crimes in history that I describe in my book Grand Theft 2000 (Kellner 2001). This spectacle was soon followed by the $9 / 11$ terror attacks on New York and Washington, the deadliest attack on U.S. soil in its history, and perhaps the most extensive global media spectacle ever, inaugurating an era of Terror War (Kellner 2003b).

Following the model of his father's 1991 war with Iraq, the second Bush administration's Iraq war was also orchestrated as a media spectacle, although after declaring victory in May 2003, events flipped out of control and the spectacle in Iraq has often been a negative and highly contested one, leading to a collapse of Bush's approval ratings and unraveling of his administration (Kellner 2005).

The Bush years have been a series of spectacles from 9/11 and Iraq to the abject failure of the Bush administration during Hurricane Katrina, [3] scandals involving criminal trials of its highest officials and top Republican congressional supporters, and in Spring 2007 a scandal that involves its Attorney General and Bush loyalist Alberto Gonzales. The spectacle of "Gonzogate" involves one of the most systematically political attempts to establish partisan control of the Justice system in U.S. history, whereby federally appointed Attorney Generals who failed to carry out Bush policies were fired, however competent, while those who carried out Bush administration politics were kept on or promoted, however corrupt or incompetent.

In addition to making a spectacle out of major political events, the media produce spectacles around events and controversies of social and everyday life, often providing forums through which major political issues and social struggles are negotiated and debated. In April 2007 alone, revelations that three Duke Lacrosse players accused of gang rape were innocent raised issues of a rogue prosecutor and prosecutorial media flying out of control. During the same week, racist and sexist comments by radio and television personality Don Imus, who called the Rutgers university women's basketball team a "bunch of nappy-headed hoes," generated a media firestorm and debate over appropriate language in regard to race and gender, the limits of free speech, and corporate media responsibility. The resultant media spectacle and focus on the event and issues led to the end of Imus's long radio career and a subsequent heated debate over the incident.

The shooting rampage at Virginia Tech on April 16, 2007 generated a media spectacle with local, national, and 
even global media following every twist of a shooting that was represented in the media as producing the highest death toll of any gun-related mass murder in recent U.S. history. [4] Such a claim was irresponsible and false and is setting the stage for someone to try to break the record. Yet the event has also generated debates over gun laws and control, school safety, mental health care, and what causes teen-agers and young students to kill their class-mates and teachers. There was also a racial dimension to the shooting as the assassin was revealed to be a Korean American Seung-Hui Cho.[5]

\subsection{Reading the Spectacle with Critical Social Theory and Cultural Studies}

In my studies of media spectacle, I deploy cultural studies as diagnostic critique, reading and interpreting various spectacles to see what they tell us about the present age, using media spectacles to illuminate contemporary social developments, trends, and struggles.[6] The "popular" often puts on display major emotions, ideas, experiences, and conflicts of the era, as well as indicating what corporations are marketing. A critical cultural studies can thus help decipher dominant trends, social and political conflicts, and fears and aspirations of the period and thus contribute to developing critical theories of the contemporary era (see Kellner and Ryan 1988 and Kellner 1995, 2003a and 2003b; and 2005).

I therefore see the spectacle as a contested terrain in which different forces use the spectacle to push their interests. Against Debord's more monolithic and overpowering totalitarian spectacle, I see the spectacle as highly contested, subject to reversal and flip-flops, and thus extremely ambiguous and contradictory. For instance, the media spectacle of the US/UK invasion of Iraq was used by the Bush administration to promote their war policy and the so-called "Bush doctrine" of preemptive war. While the spectacle went through several stages from the opening triumphant "shock and awe" bombing of Iraq through Bush's May 2003 "Mission Accomplished" spectacle, later horrific events in Iraq caused a reversal of the spectacle, and it is now hotly and bitterly contested.

Since the rise of the Centre for Contemporary Cultural Studies in Birmingham England in the 1960s, as well as in subsequent versions of cultural studies throughout the world, there has been a long-standing tradition of taking on the big issues of the era. The Birmingham School critically analyzed the assaults against working class culture by American mass media and consumer culture. In this conjuncture, British cultural studies stressed the need for media literacy and critique, learning to read newspapers, TV news, advertisements, TV shows and the like just as one learns to read books (see Kellner 1995). The project helped generate a media literacy movement, expanded the concept of literacy, and introduced a new, powerful dimension of pedagogy into cultural studies.

Later, in the 1980s, British cultural studies took on the rise of Thatcherism and the emergence of a new rightwing conservative hegemony in Britain, by explaining how British culture, media, politics, and various economic factors led to the emergence of a new conservative hegemony (see Hall and Jacques 1983). Larry Grossberg (1992), Stanley Aronowitz (1993), myself (Kellner and Ryan 1988, Kellner 1990 and 1995), and others engaged in similar work within the U.S. during the Reagan era of the 1980s, applying cultural studies to analyze the big issues of the time.

Indeed, one of my major focuses of the past two decades has been the use of cultural studies and critical social theory to interrogate the big events of the time: The Persian Gulf TV War (Kellner 1992), Grand Theft 2000: Media Spectacle and a Stolen Election (Kellner 2001), From 9/11 to Terror War on the September 11 terrorist attacks and their exploitation by the Bush administration to push through rightwing militarism, interventionism, unilateralism and a hard-right domestic agenda, including the Patriot Act (Kellner 2003b), and Media Spectacle and the Crisis of Democracy (Kellner 2005), which demonstrated how the Bush administration consistently manipulated media spectacle during its first term and in the highly contested and controversial 2004 election. In my books Media Culture (Kellner 1995) and Media Spectacle (Kellner 2003a), I use cultural studies to critically interrogate major phenomena of the day like Reagan and Rambo, Madonna and pop feminism, rap and hip hop, cyberpunk and the Internet, McDonald's and globalization, Michael Jordan and the Nike spectacle, and other defining cultural phenomena of the era.

Cultural studies is an interdisciplinary, transdisciplinary, and counter-disciplinary approach that can be used to address a wide range of cultural phenomena from advertising to political narratives (see Kellner 1995 and 2003). A multiperspectival and interdisciplinary enterprise, it draws on a number of disciplines to engage production and political economy of culture, critical engagement with texts, and audience research into effects. As a transdisciplinary 
enterprise, it has its own integrity as defined by the practices, methods, and work developing in its ever-expanding tradition. And it is counterdisciplinary, by refusing assimilation into standard academic disciplines, being open to a variety of methods and theoretical positions, and assuming a critical-oppositional stance to the current organization of the university, media, and society.

In the following study, I will illustrate my approach to merging cultural studies with critical social theory by providing a diagnostic reading of the tragic shootings at Virginia Tech in April 2007. First, I analyze the construction of the media spectacle of the Virginia Tech shooting, and how old and new media together helped produce the spectacle. Examining how the spectacle was constructed by various individuals and social groups, I analyze how the text of "The Virginia Tech Massacre" was interpreted and deployed by different individuals and groups to use the spectacle to promote their own agendas.

\subsection{The Shooting and the Politics of Race}

Initial media reports indicated that there was a shooting in a dorm on the Virginia Tech campus shortly after 7:00 A.M. on April 16. The first word was that it apparently involved a romantic clash in which a young woman and her resident dorm adviser were shot and the boyfriend was under suspicion. At the initial news conference after the first shooting, the Virginia Tech President Charles Steger stated that authorities initially believed the murder in the West Ambler Johnston dormitory was a domestic dispute and that the gunman had left campus. [7] Apparently, police who arrived at the dormitory questioned the roommate of the young woman Emily Hilscher who was the first victim of the day, said that her boyfriend had just dropped her off, and that he was a well-known gun enthusiast. This led the Virginia Tech police and administrators to believe that it was a lover's quarrel gone array, thus following prey to a stereotype of media culture.

Approximately, two hours after the West Ambler Johnson shootings reports broke out that a shooter had entered Norris Hall, which houses the Engineering Science and Mechanics program, and was at the time also the site of many language courses, and began a killing rampage. Suddenly, it was clear that a major media event was underway and representatives from all the major U.S. broadcasting networks and print publications rushed crews to the scene, as did many foreign media.

Throughout the United States, and indeed the world, web-sites like www.nytimes.com highlighted reports indicating that over 30 students and faculty were killed and that the gunman had shot himself, setting off a media frenzy that involved old and new media. Virginia Tech information web-sites like www.Planetblacksburg.com and the student newspaper site www.collegiatetimes.com were loaded with hits and many student observers of the horror posted on these or other Internet sites, or on their Facebook or MySpace pages. One enterprising young student, Jamal Albarghouti, used his mobile phone to capture the gunshots coming out of Norris Hall and police breaking in. After filming the events, Albarghouti sent it to CNN, which placed it on its online I-reports site where it was watched by millions. CNN quickly broadcast it on air, where it was replayed repeatedly and then shown by other networks. Jamal was described by CNN as our "I-reporter," interviewed throughout the day, and featured in an interview with Larry King on his Larry King Live show.

Dan Gilmor, author of the popular citizen journalism text We The Media noted: "We used to say that journalists write the first draft of history. Not so, not any longer. The people on the ground at these events write the first draft." [8] Gilmore perhaps exaggerates, but it is true that old and new media now work in tandem to piece together breaking stories with "citizen journalists" supplementing regular journalists and bloggers supplementing corporate media pundits.

As people throughout the world accessed mainstream media sources and new media, so too did mainstream reporters check out MySpace and YouTube and used material drawn for these and other new media sources. As young people from Virginia Tech disseminated cell phone video and images, as well as first person written reports put up on their own new media spaces, it was clear that new media were now playing an important role in the time of the spectacle in constructing representations of contemporary events. Old media had lost its monopoly and was forced to rely on new media, while a variety of voices and images previously omitted from the mainstream corporate media found their own sites of dissemination, discussion, and debate for, as we will see, better and worse.

Every major news corporation rushed crews and top network broadcasting people to Blacksburg in one of the most highly-saturated media sites of all time. There were estimates that at the peak of the coverage, there were more 
than 600 reporters on the scene and four or five acres of satellite television trucks.[9]

The shooter was at first described as an "Asian male," leading to a flurry of speculation. Often initial racialized attributions of the killer in a mass murder spectacle plays on deeply-rooted racism. In the Oklahoma City bombings of 1994, initial allegations targeted Arab, Middle Eastern perpetrators, setting off a paroxysm of racism. Soon after, when it was discovered that the villain was a white American Timothy McVeigh, who had fought in the Gulf War, there was shock and disbelief (see Chapter 3.12).

Likewise, on the day of the Virginia Tech shooting, as Media Matters reports:

right-wing pundit Debbie Schlussel 'speculat[ed]' in an April 16 weblog post that the shooter, who had been identified at that point only as a man of Asian descent, might be a "Paki" Muslim and part of "a coordinated terrorist attack." "Paki" is a disparaging term for a person of Pakistani descent.

Schlussel wrote, "The murderer has been identified by law enforcement and media reports as a young Asian male," adding, "The Virginia Tech campus has a very large Muslim community, many of which are from Pakistan." Schlussel continued: "Pakis are considered 'Asian," and asked, "Were there two [shooters] and was this a coordinated terrorist attack?" Schlussel asserted that the reason she was "speculating that the 'Asian' gunman is a Pakistani Muslim" was "[b]ecause law enforcement and the media strangely won't tell us more specifically who the gunman is." Schlussel claimed that "[e]ven if it does not turn out that the shooter is Muslim, this is a demonstration to Muslim jihadists all over that it is extremely easy to shoot and kill multiple American college students" (quoted from http://mediamatters.org/items/200704170006).

Soon after, the media began reporting that the murderer was "a Chinese national here on a student visa," [10] which led Schlussel and rightwing bloggers to find "[y]et another reason to stop letting in so many foreign students." Some conservative bloggers talked of how young Chinese receive military training and that this could account for the mayhem, while other rightwing web-sites and commentators argued that the Virginia Tech event showed the need for tougher immigration law.[11]

When the killer was identified as a "South Korean national," Seung-Hui Cho, and "a South Korean who was a resident alien in the United States," racist comments emerged about the violent authoritarianism of Koreans.[12] Frightened Korean students began leaving the Virginia Tech campus, Korean communities everywhere grieved, and the president of South Korea made a formal apology.[13]

This apology was not enough for the likes of Fox TV's Bill O'Reilly who argued that "the Virginia Tech killer was Korean, not American."[14] When Jam Sardar, an Iranian American and correspondent for Comcast Network, went on Fox News Channel's “O’Reilly Factor" on April 20, 2007 to discuss the question of whether representation of Cho's ethnicity was overplayed, O'Reilly did most of the talking, argued that Cho's ethnicity deserved top billing and denied that Arab Americans were victims of any significant backlash after September 11, leading Sardar to comment: "Thanks for letting me listen."

There were also speculations throughout the first day that Cho had not acted alone and that there was a second shooter. On the 8:00 p.m. CNN Paula Zahn Now, Zahn and her CNN correspondent Brianna Keilar repeatedly speculated about a second suspect, confusing what officials described as "a person of interest," probably the boyfriend of the young woman shot in the first dorm murder, with a possible second suspect. Zahn, Keilar, and others on the show spoke, however, of intense anger of Virginia Tech students that there was not an alert by the administration after the first shooting, a theme that disappeared from the mainstream corporate media soon thereafter.

Early revelations about the shooter profiled Cho as a loner who seemed to have few if any friends and who generally avoided contact with other students and teachers. There were reports that he had left a rambling note directed against "rich kids," "deceitful charlatans," and "debauchery," which police found in his dorm room and which commentators used to narrativize the event as unspecific revenge killings.

The first representation of Cho portrayed a static photo of an unsmiling, shy, sad, and rather ordinary young man in glasses, that replicated a certain stereotype of Asian-American males as nerdy, awkward, and self-effacing, but also non-threatening. Classmates interviewed on television indicated that he rarely spoke and that few knew him. Other reports recount his extreme alienation, starting in high school. There were reports that in high school Cho was mocked in school for the way that he spoke. According to a student at Virginia Tech, Chris Davids, who went to high school with Cho:

Once, in English class, the teacher had the students read aloud, and when it was Cho's turn, he just looked down in silence, Davids recalled. Finally, after the teacher threatened him with an F for participation, Cho started to read in a strange, deep voice that sounded "like he had something in his mouth," Davids said. 
"As soon as he started reading, the whole class started laughing and pointing and saying, 'Go back to China," Davids said. $[15]$

While there were reports of bullying at middle and high school, and in a Christian youth group that Cho participated in,[16] there was no evidence that he was bullied at Virginia Tech where it appears he initially tried to fit in. Yet he was obvious haunted by demons and insecurities evident in his writings, two of which from a play-writing class were posted on the Internet.[17] These texts, and previous work in his writing classes, had deeply disturbed other students who had access to them, leading one of his teachers to confront the English Department chairman about Cho. Professor Lucinda Roy, a distinguished English professor and then Chair of the Department, agreed to work with him personally, but Cho was unresponsive leading Roy and others to advise him to seek campus counseling in 2005, an event that I will return to later in the narrative.

As the media spectacle unfolded during the first days, it was generally overlooked that the Virginia Tech Massacre could be seen as an attempt to act out some of his violent fantasies and create a media spectacle in which Cho appears as the director and star. Just as Al Qaeda has been orchestrating terror events to promote their Jihadist agenda, and the Bush administration orchestrated a war in Iraq to promote its geopolitical agenda, so too have individuals carried through spectacles of terror to seek attention, revenge, or to realize violent fantasies.

In 1994, Timothy McVeigh participated in the bombing of the federal building in Oklahoma City, killing hundreds and unleashing a major media spectacle of the era-linked to the deadly U.S. government attack on a religious compound in Waco a year before (see Guys and Guns Amok Chapter 3.12).[18]

Almost exactly eight years to the day after the Oklahoma City bombing, two teenage middle-class white boys, Eric Harris and Dylan Klebold, went on a shooting rampage in Columbine, Colorado before taking their own lives (see Chapter 3). Hence, perhaps not by accident the Columbine High shootings took place on April 20, while the Oklahoma City bombings took place on April 19, 1995, on the anniversary of the government siege of Waco that killed members of a religious community some years before. While Cho's April madness preceded the April 19-20 nexus by a couple of days, he joined a constellation of American domestic male terrorists that call attention to a constellation of serious social problems in the USA today.

\subsection{Convocation and Cho's Multimedia Dossier}

The cable news networks were covering the "Virginia Tech Massacre," as it quickly became designated, in wall to wall coverage and when George W. Bush agreed to speak at a Convocation at Virginia Tech along with the Virginia governor on April 17, the two state Senators, and a congressional delegation, the major broadcasting networks put aside their soap operas and daytime programming and covered the convocation live, making it a major media event.

Although George W. Bush had avoided for years going to funerals for victims of his Iraq war, he arrived with his wife Laura ready to make a speech and then do interviews with the network broadcasting news anchors who had assembled in Blacksburg for the event. Bush was at a critical time in his presidency. His Iraq policy was opposed by the majority of the public and the Democrats appeared ready to fight Bush on his failed policy. In November 2006 Congressional Elections, Republicans lost control of the House and the Senate and committees in both chambers were investigating a series of scandals in the Bush administration. Bush's Attorney General, one of his closest operatives Alberto Gonzalez, was caught up in a major scandal and there were calls for his resignation. Questions concerning Bush's competency were intensifying and it appeared that his last months in office would be conflicted ones.

Yet, in 1995 it appeared that Bill Clinton's presidency had failed and was collapsing after Republicans won control of Congress in the 1994 off-term elections, and when Talk Radio was fiercely savaging the Clintons and inventing scandals like the so-called "Whitewater Affair" (see Lyons and Conason 2001). It is believed that after the tragedy of the Oklahoma City bombings Clinton reconnected with the public and his ratings went up steadily from that time, taking him handily through the 1996 presidential elections and enabling him to survive a major sex and impeachment scandal (see Kellner 2003a).

Could Bush also establish himself as Mourner-in-Chief and would publics rally around him as they did after 9/11? Bush's speech, live on all the major US television networks, followed Virginia Governor Timothy Kaine. Kaine took an Old Testament approach, speaking of Job and his sufferings and the mysteries of faith. Bush, by contrast, 
took a New Testament line speaking of the love and care of God for his people, suggesting that belief in God and the power of prayer would get them through their ordeal. His carefully crafted sound-byte read: "Today our nation grieves with those who have lost loved ones at Virginia Tech. We hold the victims in our hearts. We lift them up in our prayers. And we ask a loving God to comfort those who are suffering." After a few further clichés and generalities from Bush, members of the local Christian, Moslem, Judaic, and even Buddhist faith got a few minutes of national airtime to pitch their religions, before the convocation turned inward to Virginia Tech concerns and the major broadcasting networks cut off their coverage.

Bush and his wife Laura were interviewed for the major news networks that night and it was clear that he was not even going to consider stricter gun control laws and by the weekend the buzz word for his administration was "mental health," a safe topic that could replace gun control for national debate and political action. It is unlikely that Bush's performance as Consoler-in-Chief would help him much as the following day there were some of the most deadly bombings in the Iraq war and by the end of the week hundreds of Shiites were dead from terrorist bombings, Shia politicians were pulling out of the government, and it appeared the Iraq debacle was worsening. And on Thursday April 19, 2007 a congressional grilling of Bush's Attorney General Alberto Gonzalez produced such an inept and embarrassingly incompetent performance that even conservative republicans were calling for his resignation.

Meanwhile, intense media focus continued to unravel facts about the assassin Cho, about his victims and acts of heroism, and about failures of the Virginia Tech administration to deal with Cho and the resultant crisis. A multimedia package that Cho mailed to NBC News on April 16, apparently after the first murder in the dorm, and widely shown on April 18, revealed that Cho indeed was planning a media spectacle in the tradition of the Columbine shooters who he celebrated as "martyrs."

A picture and video gallery in the multi-media dossier sent to NBC is said to have contained a DVD which held 27 video clips, 43 captioned still photos, and a 1800 word document that could reproduce the rant that was reported on the first day.[19] The material made it clear that Cho was planning to carry out himself a plan that he had constructed as "Massacre at Virginia Tech." One of the photos in which Cho posed with a hammer in his hand reprises the Korean "Asian Extreme" film Oldboy,[20] which itself is a revenge fantasy in which a young Korean inexplicably imprisoned in a room goes out a rampage of revenge against his captors. Another pose shows Cho pointing a gun at his own head, another iconic image of Oldboy, which in turn is quoting Robert de Niro's famous scene in Taxi Driver, in which he follows a slaughter of perceived villains with a suicidal blowing of his head apart, just as Cho did. Further, as Stephen Hunter argues, much of the iconography in the photo gallery quotes poses in films by Hong Kong action director John Woo, as in the images where Cho holds two guns in his hands, and points a gun at a camera. Further, Cho brandishes Beretta and Glock guns featured in Woo's movies, that include The Killer where a professional assassin goes down a corridor, enters a room, and systematically mows down its occupants.[21]

The transformation of Cho's image was striking. The shy nerdy student was suddenly aggressively staring in the camera with cold and calculating eyes, tightly holding guns, wearing a backwards black baseball cap, fingerless black gloves, and a black T-shirt under a khaki photographer-style vest. When he spoke in a mocking monotone, he spit out belligerent taunts and verbal assaults at all and sundry, laced with obscenities. Cho's construction of a violent masculinity is apparent in the gap between the first still photo and his multimedia dossier when he assumes the guises and paraphernalia of of an alpha dog, ultra-macho man. The very exaggeration and hyberbole of the dossier, hardly a "manifesto" as Brian Williams of NBC described it when he introduced it to a shocked nation, calls attention to the constructedness and artificiality of hypermaleness in US society. Further, his extreme actions call attention to the potential destructiveness and devastation in assuming an ultra-macho identity. Since Cho was apparently not able to construct a normal student and male identity, he obviously resorted to extremity and exaggeration.

Cho's literary expressions in his dossier and personal symbols also point to an aesthetic of excess. Earlier reports indicated that Cho had written in ink "Ismail Ax" on his arm. The "Ismail Ax" reference, led some conservatives to conclude that Cho was Islamic inspired. Jonah Goldberg, for instance, speculated that:

First it was Johnny Muhammad, now it was Cho Sueng Hui aka Ismail Ax. Precisely how many mass shooters have to turn out to have adopted Muslim names before we get it? Islam has become the tribe of choice of those who hate American society... I'm talking about the angry, malignant, narcissist loners who want to reject their community utterly, to throw off their 'slave name' and represent the downtrodden of the earth by shooting their friends and neighbors.

This morning I read that the Virginia Tech shooter died with the name Ismail Ax written in red ink on his arm. The mainstream press doesn't seem to have a clue as to what this might mean. To quote Indiana Jones, "Didn't any of you guys go to Sunday School?"[22] 
But on the evening of April 18, NBC reported that the package with the multimedia dossier was addressed as sent from "A. Ishmael." The latter literary spelling of the Old Testament and Koranic "Ismail" could refer to the opening of Herman Melville's classic Moby Dick, where the narrator begins with "Call me Ishmael." This reading would position the shooter as on a revenge quest, as was Captain Ahab against the White Whale, Moby Dick. But it also positions Cho himself within the great tradition of American literature, as Ishmael is the narrator of one of the United States's great novels. Another Internet search noted that the literary character Ishmael is also "tied to James Fenimore Cooper's novel The Prairie, Ishmael Bush is known as an outcast and outlawed warrior, according to an essay written in 1969 by William H. Goetzmann, a University of Texas History professor. In Cooper's book, 'Bush carries the prime symbol of evil—the spoiler's axe,' the professor wrote.'[23]

Perhaps the Ishmael Ax moniker positions Cho as well in the tradition of Hollywood and Asian Extreme gore films featuring $\operatorname{Ax}(\mathrm{e})$ murderers, as other photos in his dossier show him with knives and hammer in hand, iconography familiar from horror and gore films, which he had apparently studied.[24]

Yet, Ismail/Ishmael is also a Biblical name, prominent in both the Judaic and Islamic religions. As Richard Engel points out: "Ismail is the Koranic name of Abraham's first-born son. In one of the central stories of the Koran, God orders Abraham (called Ibrahim) to sacrifice Ismail as a test of faith, but then intervenes and replaces him with a sheep. Muslims reenact this story by sacrificing a sheep on Eid al-Adha (feast of the sacrifice) during the Hajj, the annual pilgrimage to Mecca).’'[25]

Cho's references in his text thus span high and low culture and various religious and literary traditions in a postmodern pastiche. The references to Christ in his rambling "manifesto" position Cho himself as sacrificial and redemptive, although he also blames Jesus for his rampage, writing: "You have vandalized my heart, raped my soul and torched my conscience. You thought it was one pathetic boy's life you were extinguishing. Thanks to you, I die like Jesus Christ, to inspire generations of the weak and the defenseless people." But then: "Jesus loved crucifying me. He loved inducing cancer in my head, terrorizing my heart and ripping my soul all this time."

Another excerpt from his text positions Cho as a domestic terrorist carrying out a revenge fantasy when he writes: "you had a hundred billion chances and ways to have avoided today.... But you decided to spill my blood. You forced me into a corner and gave me only one option. The decision was yours. Now you have blood on your hands that will never wash off."

The "you" in the message seems to refer to all the fellow students and teachers who failed to grasp his creative genius and who ridiculed his writings and behavior. "You" also could refer to you and I more generally as part of a culture that Cho has could come to violently and psychotically reject, although "You" could also refer to the media itself as his inspiration, for his sick murder rampage was clearly based on media culture and its vehicle was media spectacle.

Cho thus can be seen as a domestic terrorist assassin in the tradition of Timothy McVeigh, the Unabomber, and the two Columbine shooters (see Chapter 3), the latter of whom he mentions in the text as "martyrs." Richard Engel, NBC's Middle East Bureau chief noted in his blog that Cho's "testimony" videos were grimly reminiscent of suicide bombers who left videos explaining their actions and trying to justify themselves with grievances and higher purposes.[26] But Cho also positions himself as a vehicle of class revenge:

You had everything you wanted. Your Mercedes wasn't enough, you brats. Your golden necklaces weren't enough, you snobs. Your trust fund wasn't enough. Your vodka and Cognac weren't enough. All your debaucheries weren't enough. Those weren't enough to fulfill your hedonistic needs. You had everything.

The ensuing media spectacle apparently achieved what the crazed Cho had in mind, a spectacle of terror a la the 9/11 terror attacks which attracted scores of media from all over the world to Blacksburg in saturation coverage of the event. His carefully assembled multi-media package revealed to the world who Cho was, and won for him a kind of sick and perverted immortality, or at least tremendous notoriety in the contemporary moment.

There was a fierce, albeit partially hypocritical, backlash against NBC for releasing the media dossier and making a potential hero and martyr out of Cho. No doubt, any network getting such a scoop would broadcast it in the current frenetic competition for media ratings, and all of the networks gave saturation coverage to the dossier, each image of which was burned with the NBC logo, just as earlier video camera footage of the gunshots echoing from Norris Hall all contained the CNN logo.

Cho was media savy enough to know that NBC (or any television network) would broadcast his material, while it is well-known that the police in the Columbine shootings only later released small portions of the killers' videos 
and writings. It should also be pointed out that Cho's videography and picture posing replicated the form of young people's posting on sites like MySpace or Facebook, while his video is similar to the kinds of postings young people put on YouTube. Previously, Cho's Facebook nom de plume was QuestionMark?, a phrase he also used in textmessaging. Now the world had at least some idea who Seung-Hui Cho really was, although many question marks remain.

\section{| 1.4 Guns and Political Scapegoating}

Every time that there is a significant school, university, or workplace shooting, there is discussion of the need for stricter gun laws, but after some brief discussion the issue falls away. After Virginia governor Timothy Kaine returned to Blacksburg from a Tokyo trade conference on April 17 of the Virginia Tech Convocation, he announced that he would appoint a panel at the university's request to review the authorities' handling of the disaster. But, in a widely quoted statement, he warned against making snap judgments and said he had "nothing but loathing" for those who take the tragedy and "make it their political hobby horse to ride." [27]

The pro-gun lobby, however, and rightwing pundits, was ready with its ammunition and took an offensive role. Rightwing Internet sites began immediately claiming that the fact that Virginia had banned guns from state universities meant that there were no student shooters able to take down the assailant. I saw this position articulated on MSNBC the day of the shooting itself by a Denver law school professor with the MSNBC Live anchor Amy Robach agreeing that the scale of murder might have been reduced if students were allowed to carry guns. A sane gun authority on the show reacted with horror to the idea of having unrestricted guns on campus, but was cut off by the anchor and not able to articulate his position. Indeed, consider having a classroom, dorm, or public university space full of armed students, faculty, or staff, who might go off on a sudden whim, and one can easily imagine a daily massacre in a gun-saturated America.

While both sides on the gun controversy tried to get out their points of view, the pro-gun control side was quickly marginalized, as I will show. Initially, however, in Sacha Zimmerman's summary:

Before the blood had even dried at Tech, the gun-control debate erupted. Both sides of the issue seemed to be in a race for the first word, for the best spin. "It is irresponsibly dangerous to tell citizens that they may not have guns at schools," said Larry Pratt, executive director of Gun Owners of America. Meanwhile, White House spokeswoman Dana Perino was quick to awkwardly assure the world that the president still believes in the right to bear arms. And Suzanna Hupp, a former Texas state representative and concealed-weapons advocate, appeared on CBS's The Early Show not 24 hours after the shootings for a debate: "Why are we removing my teachers' right to protect themselves and the children that are in their care?" Her opposition, Paul Helmke, president of the Brady Center to Prevent Gun Violence, swiftly sprung into action: "Let's prevent these folks from getting these guns in the first place.... If they can't get that gun with a high-powered clip that's shooting off that many rounds that quickly, then we're making our community safer."[28]

The corporate broadcasting media, however, allowed few pro-gun control voices to be heard. Representative Carolyn McCarthy (D-NY), whose husband was killed and son seriously injured in a Long Island Rail Road shooting, was on several networks. She urged House leaders to move quickly to push forward stalled legislation that would improve data bases that could be used in conducting criminal background checks on potential gun purchasers, an issue she had been pushing for years. While Philip Van Cleave, President of the Virginia Citizens Defense League conceded that allowing faculty and students to carry guns might not have prevented the rampage, he claimed that at least “they wouldn't die like sheep,... but more like a wolf with some fangs, able to fight back.”[29] The macho Right, in fact, attacked the Virginia Tech students for not fighting back more ferociously against the assassin. As Media Matters compiled the story:

In the April 18 edition of his daily program notes, called Nealz Nuze and posted on his website, nationally syndicated radio host Neal Boortz asked: "How far have we advanced in the wussification of America?" Boortz was responding to criticism of comments he made on the April 17 broadcast of his radio show regarding the mass shooting at Virginia Tech. During that broadcast, Boortz asked: "How the hell do 25 students allow themselves to be lined up against the wall in a classroom and picked off one by one? How does that happen, when they could have rushed the gunman, the shooter, and most of them would have survived?" In his April 18 program notes, Boortz added: "It seems that standing in terror waiting for your turn to be executed was the right thing to do, and any questions as to why 25 students didn't try to rush and overpower Cho SeungHui are just examples of right wing maniacal bias. Surrender-comply-adjust. The doctrine of the left. ... Even the suggestion that young adults should actually engage in an act of self defense brings howls of protest." 
In the April 17 edition of his program notes, Boortz had similarly asked: "Why didn't some of these students fight back? How in the hell do you line students up against a wall (if that's the way it played out) and start picking them off one by one without the students turning on you? You have a choice. Try to rush the killer and get his gun, or stand there and wait to be shot. I would love to hear from some of you who have insight into situations such as this. Was there just not enough time to react? Were they paralyzed with fear? Were they waiting for someone else to take action? Sorry ... I just don't understand." [30]

Boortz and other rightwing macho Rambos dishonor the heroism of professors and students who blocked classroom doors, with one elderly 76 year old professor, holocaust survivor Liviu Librescu, getting killed trying to block the door shut so students could escape out the window. Another professor and his students were able to block the door of their classroom and prevent Cho from entering. Further, there could well be untold tales of heroism, as well as many documented ones.[31]

Rightwing response to the Virginia Tech tragedy was both appalling and revealing. Some prominent rightist commentators took the occasion of the tragedy and intense media spectacle to bash liberals or their favorite targets. Media Matters reported that “(o)n the April 19 broadcast of his nationally syndicated radio show, host Rush Limbaugh declared that the perpetrator of the April 16 Virginia Tech shootings "had to be a liberal," adding: "You start railing against the rich, and all this other-this guy's a liberal. He was turned into a liberal somewhere along the line. So it's a liberal that committed this act."'[32] But it is doubtful Cho had a coherent political ideology, and he clearly inserted himself in the tradition of domestic terrorists including the Columbine shooters and Timothy McVeigh, hardly "liberal."

Professional '60s-basher Thomas Sowell blamed the Virginia Tech and Columbine shootings on '60's culture and its alleged "collective guilt" that supposedly blamed " 60 s urban violence on society and somehow sent out the message that it was okay to kill people because it's all society's fault.[33] Sowell's failure in argument and reasoning is stunning, as no one makes the arguments about the ' $60 \mathrm{~s}$ he claims, and puts on display the simple-minded tendency of rightwing ideologues to blame everything on their own pet peeves and ideological obsessions.

But the most extreme example of rank hypocrisy and political exploitation of the Virginia Tech tragedy was a dual intervention by Washington Post columnist Charles Krauthammer. Krauthammer, one of the most enthusiastic advocates to this day of the Iraq war, reasonably wrote in his April 19 Washington Post column that it is terribly inappropriate to exploit tragedies like the Virginia Tech shootings to make ideological arguments. But later in the day and less than 48 hours after the shooting, Krautheimer was on Fox News exploiting the shootings to promote one of his personal hobby horses. As Glen Greenwood notes in his Salon blog, Krautheimer just couldn’t help running to Fox News “to explain why the Virginia Tech shootings and the killer's 'manifesto' are connected to Al Jazeera, the Palestinians and other Muslim Enemies who dominate Krauthammer's political agenda":

KRAUTHAMMER: What you can say, just-not as a psychiatrist, but as somebody who's lived through the a past seven or eight years, is that if you look at that picture, it draws its inspiration from the manifestos, the iconic photographs of the Islamic suicide bombers over the last half decade in Palestine, in Iraq and elsewhere.

That's what they end up leaving behind, either on al Jazeera or Palestinian TV. And he, it seems, as if his inspiration for leaving the message behind in that way, might have been this kind of suicide attack, which, of course, his was. And he did leave the return address return "Ismail Ax." "Ismail Ax." I suspect it has some more to do with Islamic terror and the inspiration than it does with the opening line of Moby Dick [the bold marks are by Greenwood].[34]

In fact, the "Ismail" and "Ishmael" references in Cho's testimony could refer to the Ishmail character in either the Old Testament or the Koran, or it could refer to Moby Dick's narrator Ishmael, or a hybridized fantasy of Cho's deranged and disordered mind. Krautheimer's blaming the massacre on "Al Jazeera, the Palestinians and other Muslim Enemies" give us insight into Krautheimer's deranged and disordered mind that sees his Muslim enemies at work everywhere from Iraq to Blacksburg Virginia.

Never missing an opportunity to attack pharmaceuticals, the "church" of Scientology cited Cho's reported use of antidepressants and sent twenty of its "ministers" to Blacksburg to help with the "healing" process. A scientologist spokesperson Sylvia Stannard claimed that the killings demonstrate "these mind-altering drugs" make "you numb to other people's suffering. You really have to be drugged up to coldly kill people like that." Indeed, according to a report by George Rush and Joanna Rush Molloy: "Even before Cho's name was released, the Citizens Commission on Human Rights, a group founded by the church [of Scientology], said in a press release that 'media and law enforcement must move quickly to investigate the Virginia shooter's psychiatric drug history-a common factor amongst school shooters."'[35] 
Obviously, Cho had major mental health issues, and serious psychiatrists saw clinical evidence in Cho's dossier, writings and behavior of classical paranoid schizophrenia,[36] that itself could be genetically generated or the product of some terrible brain disorder, while others saw evidence of depression, acute autism, or various forms of psychosis, or claimed that there was no evidence he suffered from any specific mental illness.[37] Yet such disease is itself overdetermined and often impossible to pinpoint the exact casual etiology, just as shootings like the Columbine rampage are socially overdetermined. Medical reductions cover over the social problems that school shootings and societal violence call attention, just as do the repeated evocations by pundits that Cho was simply "insane," and that this explains everything, or that he was an exemplar of "radical evil," another popular conservative (mis)explanation.

After school or workplace shootings or similar events that become media spectacles, there are demands for simple explanation, scapegoats, and actions. After the Columbine shootings, certain pundits attacked the Internet, Marilyn Manson and various forms of goth or punk music and culture, violent films and television, video games, and just about every form of youth culture except bowling. In Cho's case, his alleged earlier interest in video games, his deep Internet fascination, and his seeming affinity for violent movies could lead some to scapegoat these forms of youth culture. This would be, I believe, a serious mistake. Rather than ban media culture from the lives of youth and its study from schools, I would advocate critical media literacy as an essential part of education from early grade schools through the university level (see Kellner 1995 and Chapter 4 Guys and Guns Amok).

In addition, however, I want to argue for multiperspectivist interpretations of events like the Virginia Tech Massacre or the Columbine Shootings (or for that matter for political events like the Iraq war). We still do not know exactly why the Columbine shootings took place and there are no doubt a multiplicity of factors ranging from the experiences at school of the extremely alienated teenage boys, to any number of cultural influences, including the culture of violence and violent gun culture in the US, or specific familial or individual experiences. As Michael Moore and a father of one of the teenagers shot at Columbine concluded in the film Bowling for Columbine, there's no one simple answer to why there is so much gun violence in the United States, but rather a variety of interacting causes, requiring multi-causal explanation (Guys and Guns Amok Chapter 3.32).

Likewise, we may never know why Cho choose to engineer and orchestrate the Virginia Tech Massacre and from his multimedia dossier it is clear that there were a range of influences spanning violent Korean and Asian films, the Columbine shooters who he referred to as "martyrs", religious texts and references ranging from the Koran to the both the Old and New Testaments of the Bible, to possible literary influences. Reports of his life indicate that earlier he was devoted to basketball and video games and his dorm-mates note that he spent hours on the computer, often listening repeatedly to certain songs. Such reports were used to attack Internet games,[38] but few criticized his basketball obsession as fuelling murderous fantasies. Moreover, one report indicated that he wrote the lyrics to his favorite Collective Soul song "Shine," that he reportedly repeatedly listened to, on the walls of his dorm room:

Teach me how to speak

Teach me how to share

Teach me where to go

Tell me will love be there [39]

While the disappointment of such yearning could inspire rage, it is ludicrous to blame the music, or any one of Cho's media cultural influences, for the Virginia Tech Massacre, and pundits who pick out any single influence, usually one of their favorite targets, are irresponsible. Complex events always have a multiplicity of causes and to attempt to produce a single-factor explanation or solution is simplistic and reductive. As noted, Cho also had creative ambitions, understood the workings of the media and media spectacle, and carefully planned his moments of infamy. No doubt more facts and information may emerge concerning Cho's influences, motivations, and warped actions, but it would be wrong to at this time try to provide a one-sided interpretation or explanation.

Yet there is no doubt that he became obsessed with guns and violence gun culture during his last days. There are reports that he had thoroughly immersed himself in the culture of gun violence, buying one gun from a local store and another over the Internet, where the seller indicated he appeared a highly knowledgeable gun consumer. Cho bought ammunition from the Internet, went to a gym to buff himself up, went to a shooting range to engage in target practice, and thoroughly immersed himself in ultramasculinist gun culture.

Yet a constellation of influences helped construct Cho and we may probably never know the precise influences 
of media culture, models of masculinity, gun culture, and the specific environmental influences of family, school, and social life. The overdetermined nature of events like school shootings requires multiperspectivist analysis and contextualizing the event in the life-situation of those involved. I have criticized certain one-sided interpretations of Cho's rampage and shown how the media spectacle of the "Virginia Tech Massacre" has been a contested event. In my forthcoming book Guys and Guns Amok, I put the Virginia Tech shootings in the context of analyses of alienation of youth, domestic terrorism, the construction of masculinist male identities in media culture and gun culture, and situate Cho in a constellation that includes Timothy McVeigh and the Oklahoma City bombings, the Unabomber, and the Columbine school shootings to provide examples of individuals who construct their identities and produce media spectacles to advance their politics in a context of guns and men running amok. Hence, the sketch here of the "Virginia Tech Massacre" is provisional and requires a broader context to fully engage.

\section{Endnotes}

1. I am using the term "The Virginia Tech Massacre" because this was the phrase that the major broadcasting networks used from the beginning and continued to use through the opening days of the spectacle. This text is part of a larger project where I engage the spectacle of the Virginia Tech Massacre and put it in the context of the domestic terrorism of the Oklahoma City bombings, the Unabomber, and the Columbine High School shootings. The book, Guys and Guns Amok: Domestic Terrorism and School Shootings from the Oklahoma City Bombings to the Virginia Tech Massacre, will be published by Paradigm Press later this year. Thanks to Jennifer Knerr and Henry Giroux for facilitating a fast contract and for helpful comments on the text. Finally, I am putting all articles referenced in footnotes, most of which have hypertext links, while am referencing books in standard form.

2. My notion of media spectacle builds on French theorist Guy Debord's society of spectacle (1967), but differs significantly from Debord's concept (see Kellner 2003a and 2005). Debord's The Society of the Spectacle (1967) was published in translation in a pirate edition by Black and Red (Detroit) in 1970 and reprinted many times; another edition appeared in 1983 and a new translation in 1994. The key texts of Debord and his group the Situationist International are found on various Web sites, producing a curious afterlife for Situationist ideas and practices. For further discussion of Debord and the Situationists, see Best and Kellner 1997, Chapter 3; see also the discussions of spectacle culture in Best and Kellner 2001 and Kellner 2003a.

3. See Douglas Kellner, The Katrina Hurricane Spectacle and the Crisis of the Bush Presidency," Cultural Studies $<>$ Critical Methodologies, Vol. 7, Nr. 2 (May 2007):222-234, and Giroux 2006.

4. Thanks to Christine Kelly for e-mailing me (April 23, 2007) that: What also has to be challenged is the media's assertion that the VTech tragedy is the "deadliest mass shooting in U.S. history". This isn't true. According to Peter Hart on FAIR 's (Fairness and Accuracy in Reporting) "CounterSpin" radio program this week, "The 1873 massacre of Black militia soldiers during Reconstruction left an estimated 105 dead, the Sand Creek Massacre of Cheyenne left a comparable death toll, Wounded Knee was a massacre of around 300, the 1921 killings in Tulsa, OK...killings of AfricanAmericans in what is often referred to as "The Black Wall Street" left dozens dead". I would add to that the 1871 killing of 19 Chinese men and boys in Los Angeles and the 1885 massacre of 28 Chinese were killed and 15 wounded, some of whom later died, in Rock Springs, Wyoming. This is not to diminish what happened at VTech but if the media wants to make statements regarding an incident's historical context they should take the time to make sure they do the research. Or, perhaps, the killings of Native-Americans, Asians and African-Americans by white mobs don't really matter.

5. Following Korean conventions of listing the family name first, the Virginia Tech shooter was first referred to Cho Seung-Hui in the U.S. media, but the family intervened and requested the more Americanized designation Seung-Hui Cho, and I will follow this convention here.

6. On diagnostic critique, see Kellner and Ryan 1988 and Kellner, 1995, pp. 116-117.

7. Hank Kurz, Jr. "Questions Raised on Va. Tech Security." Washington Post, Associated Press report. April 16, 2006, retrieved on 2007-04-16. See also Michael D. Shear, "Campus Shutdown never Considered," Washington Post, April 22, 2007:A01, which indicates that when Virginia Tech president Charles W. Steger and his top lieutenants gathered to assess the first shooting, they were called from the dorm by Campus Police Chief Wendell Flinchum who informed them that the police were on top of the case and were on the trail of the dead student's boyfriend, the suspect in the killing. Obviously, this assumption was dead wrong and a debate has unfolded concerning what the proper response should have been after the initial shooting.

8. Gilmore was quoted in Bobbie Johnson and Conor Clarke, "America's first user-generated confession. The U.S. college shooting marked a watershed moment for old and new media." The Guardian, April 23, 2007 at 
http://media.guardian.co.uk/site/story/0,,2063112,00. html.

9. Michael Bush, "Virginia Tech creates comms team in wake of tragedy," PRWeek, April 23, 2007 at http:// www.prweek.com/us/sectors/crisiscommunications/ article/651936/Virginia-Tech-creates-comms-teamwake-tragedy/.

10. This story was first reported by Michael Steed in the Chicago Sun-Times who claimed that the suspect was "a Chinese national who arrived in the United States last year on a student visa ...[who]... reportedly arrived in San Francisco on a United Airlines flight on Aug. 7, 2006, on a visa issued in Shanghai" at www. SunTimes.com (no longer accessible). The story quickly disappeared from the paper's web-site but not before it circulated through mainstream broadcasting media networks and the Internet.

11. For instance, see the posting by Peter Brimlow, "Virginia Tech Massacre: Gun Control-Or Immigration Control?", April 18, 2007 at at the rightwing blog http://www.vdare.com/pb/070418_ vt.htm.

12. On the fringes, there was speculation by Mae Brussell on whether Cho had CIA or Moonie connections given South Korea's close connections with the CIA and whether Cho was a Manchurian candidate whose programming ran amok, or was intended to divert attention from Bush administration scandals; see Brussells, "The Conspiracy Theory Blog" which continues to probe Cho/CIA/Moonie connections at http://theconspiratorsnest.blogspot.com/search/ label/VaTech\%20Massacre (accessed May 13, 2007). See also, Paul Joseph Watson, "Seung-Hui Cho Was a Mind Controlled Assassin," Prison Planet, April 19, 2007 at http://www.prisonplanet.com/print.php (Accessed June 2, 2007).

13. See Sandy Banks, "Ethnicity brings an unwelcome focus," Los Angeles Times, April 19, 2007:A01.

14. Bill O'Reilly, "Politics and Mass Murder," April 18, 2007 at http://www.foxnews.com/ story/0,2933,266711,00.html.

15. See Matt Apuzzo, "Former high school classmates say Va. Tech gunman was picked on in school," Associated Press, April 19, 2007 at http://www.thetimesnews.com/ onset id $=903 \&$ template $=$ article.html.

16. Evan Thomas, "Quiet and disturbed, Cho Seung-Hui seethed, then exploded. His odyssey." Newsweek, April 30, 2007 at http://www.msnbc.msn.com/id/18248298/ site/newsweek/.

17. Two of Cho's plays were available on-line on April 21, 2007 at http://news.aol.com/virginiatech-shootings/cho-seung-hui/_a/richard-mcbeefcover-page/20070417134109990001. In its inimitable fashion, when these artifacts emerged on the Internet, a New York Post headline read "PSYCHO PENNED
POISON PLAYS," by LEELA de KRETSER and KATE SHEEHY, April 18, 2007 at http://www.nypost.com/ seven/04182007/news/nationalnews/psycho_penned_ poison_plays_nationalnews_leela_de_kretser_and_ kate_sheehy.htm.

18. We still do not know exactly who participated in the Oklahoma City bombings (see Chapter 3 of Guns Amok, forthcoming, for discussion of various theories).

19. Cho's multimedia dossier was archived at http:// boingboing.net/2007_04_01_archive.html (accessed May 8, 2007).

20. The phrase "Extreme Asia" was a marketing slogan used to highlight an extreme form of horror and violence film emerging in Asia over the last decade, and the Sundance Channel regularly features "Asian Extreme" films. Oldboy (2004) is one of the most praised of this genre; made by Korean director Chanwook Park, it is part of his "vengeance triology." Curiously, Park directed the second segment of Three Extremes (2005), an Asian Extreme Horror fest by major Hong Kong, Korean, and Japanese directors. Park's segment features a successful director terrorized by one of the extras from his films who kidnaps his family, cuts off fingers of his pianoplaying wife, induces the director to tell of his infidelity and to kill a young girl in the house. The crazed extra wants to demonstrate that although the director is rich, successful, famous, and thinks he is "good," he is no better than the pathetic extra. Bizarrely, the extra who torments the director looks quite similar to Cho.

21. Stephen Hunter, "Cinematic Clues To Understand TheSlaughter Did Asian Thrillers Like 'Oldboy' Influence the Va. Tech Shooter?,"Washington Post, April 20, 2007; Page $\mathrm{C} 01$ at http://www.washingtonpost.com/wpdyn/content/article/2007/04/19/AR2007041901817. html?hpid=topnews. A.O. Scott attacked Hunter's article, putting it in the context of attempts to blame media culture for shootings or acts of terror, but, in fact, Hunter does not overstep his claims on influence and was the first to call the attention to the uncanny resemblance between Cho's dossier and images in Asian Extreme films. See A.O. Scott, "Drawing a Line From Movie to Murder," New York Times April 23, 2007 at http:// www.nytimes.com/2007/04/23/movies/23movi. $\mathrm{html}$ ? ex $=1180843200 \&$ en $=9 \mathrm{bb} 670 \mathrm{a} 87240317 \& \mathrm{ei}=50$

70 I take the mediated position that media culture may have significant impact on behavior but should not be stigmatized or demonized as it is at most one factor among many in influencing violent behavior (see Kellner 1995).

22. Jonah Goldberg, National Review blog at http://corner.nationalreview.com/ post $/$ ?q=MWJINDUxODE4NjQ5NGY3NjlmMGY4M WIOOGRkNjJhODE=

23. See "No Answers," The Tampa Bay Times, April 18, 2007 at http://www.tbt.com/america/ataglance/ article38944.ece.

24. It was reported that Cho had taken courses in contemporary horror films and literature, a fact that 
enabled conservatives to attack the study of popular culture and literature. See Marc Santora and Christine Hauser, "Anger of Killer Was on Exhibit in His Writing", New York Times, April 20, 2007 at http://www.nytimes. com/2007/04/19/us/19gunman.html.

25. Richard Engel, “Cho's 'religious' martyrdom video," at http://worldblog.msnbc.msn.com/ archive/2007/04/19/157577.aspx. Another reading was offered by the New York Post cited by the New York Times' blog "the Lede" at http://thelede.blogs.nytimes. com/tag/virginia/:

"The reference may be to the Islamic account of the Biblical sacrifice of Abraham, where God commands the patriarch to sacrifice his own son. Abraham begins to comply, but God intervenes at the last moment to save the boy ... Abraham uses a knife in most versions of the story, but some accounts have him wielding an ax. A more obscure reference may be to a passage in the Koran referring to Abraham's destruction of pagan idols; in some accounts, he uses an ax to do so. I should emphasize that these readings are all hermeneutical constructions and we will probably never know what meanings Cho was assigning to his text.

26. Richard Engel, op. cit.

27. Matt Apuzzo, "Va. Tech gunman writings raised concerns," Associated Press Writer Tue Apr 17, 2007 at http://news.yahoo.com/s/ap/20070417/ap_on_re_us/ virginia_tech_shooting.

28. Sacha Zimmerman, "The true roots of the Virginia Tech massacre. Generation Columbine, TNR Online, April 19m 2007 at http://www.tnr.com/doc. mhtml?i=w070416\&s=zimmerman041907.

29. Leslie Eaton and Michael Luo, "Shooting Rekindles Issues of Gun Rights and Restrictions," New York Times, April 18, 2007 at http://www.nytimes. com/2007/04/18/us/18pistols.html?ref=us.

30. "Boortz, others blame VA Tech victims for not fighting back,"at http://mediamatters.org/ items/200704180007. Media Matters further notes that:

In questioning the actions of Virginia Tech students involved in the April 16 incident, Boortz joined the ranks of various commentators, including National Review Online contributor John Derbyshire, Chicago Sun-Times columnist Mark Steyn, who also writes for the National Review, and right-wing pundit and Fox News analyst Michelle Malkin.

In an April 17 weblog post on National Review Online's The Corner, Derbyshire asked: "Where was the spirit of self-defense here? Setting aside the ludicrous campus ban on licensed conceals, why didn't anyone rush the guy? It's not like this was Rambo, hosing the place down with automatic weapons. He had two handguns for goodness' sake-one of them reportedly a .22." Time.com Washington editor Ana Marie Cox criticized Derbyshire in an April 17 post on
Time magazine's political weblog, Swampland.

Steyn and Malkin have made similar statements, as the weblog Think Progress noted. In her April 18 syndicated column, Malkin wrote: "Instead of encouraging autonomy, our higher institutions of learning stoke passivity and conflict-avoidance. And as the erosion of intellectual self-defense goes, so goes the erosion of physical self-defense." In his April 18 National Review column, Steyn suggested that Virginia Tech students were guilty of an "awful corrosive passivity" that is "an existential threat to a functioning society." (op. cit.)

31. For a detailed account of the shooting, see David Maraniss, "'That Was the Desk I chose to Die Under," Washington Post, April 19, 2007: A01. See also Raymond Hernandez, "Inside Room 207, Students Panicked at Rampage and Then held Off Gunman's Return," New York Times, April 18, 2007.

32. "Limbaugh said Virginia Tech shooter "had to be a liberal"” at http://mediamatters.org/ items/200704190008.

33. Thomas Sowell, “Are Today's Mass Shootings a Consequence of ' 60 s Collective Guilt?" The Baltimore Sun, April 26, 2007: 19A.

34. Glen Greenwood, "Charles Krauthammer takes rank hypocrisy to new lows," Salon, April 20, 2007 at http:// www.salon.com/opinion/greenwald/2007/04/20/ krauthammer/print.html.

35. George Rush and Joanna Rush Molloy, "Critics: Scientologists' Va. Trip A Time to Prey," Daily News (New York), April 18, 2007: p. 24. Unfortunately, for the scientologists' crusdade against prescriptive drugs, a toxicology report indicated that there was no evidence of prescriptive drugs or toxic substances found in Cho. See "Cho's toxicology report released, Tech announces changes," Collegiate Times, June 21, 2007 at http://collegiatetimes.com/news/1/ ARTICLE/9130/2007-06-21.html(accessed June 23, 2007). While I think it is a mistake a la the scientologists to blame school shootings on prescriptive drugs tout court, there are serious concerns about overprescription and misprescription of dangerous drugs that I do not want to ignore.

36. See, for example, Michael Welner, "Cho Likely Schizophrenic, Evidence Suggests," ABC News, April 17, 2007 at http://abcnews.go.com/Health/VATech/ story? $\mathrm{id}=3050483$.

37. For wide-ranging discussion of the psychiatric debates concerning Cho's condition, that no one can obviously definitively resolve at this point, see the openminded and ended discussions on Robert Lindsay's blog at http://robertlindsay.blogspot.com/2007/04/didcho-have-prodromal-paranoid.html.

38. Anti-video game activist Jack Thompson appeared on Fox News the day of the shooting to point the finger of blame at video games, and Dr. Phil appeared 
on Larry King Live to attack video games; see Winda Benedetti, "Were Video games to blame for massacre? Pundits rushed to judge industry, gamers in the wake of shooting," MSNBC Commentary, April 20, 2007 at http://www.msnbc.msn.com/id/18220228/. The commentary notes that the Washington Post had just pulled a paragraph from a story that claimed Cho was an avid fan of the game "Counter-Strike," and then indicated that no video games were found in his room and that his suite-mates had never seen him play video games.

39. Cited in Nancy Gibbs, "Darkness Falls," Time, April 19, 2007 at http://www.time.com/time/magazine/ article/0,9171,1612715,00.html.

\section{References}

Aronowitz, Stanley. 1993. Roll Over Beethoven. Hanover, New Hampshire: University Press of New England.

Best, Steven and Douglas Kellner. 2001. The Postmodern Adventure: Science, Technology, and Cultural Studies at the Third Millennium. New York:Guilford.

Giroux. Henry. Stormy Weather: Katrina and the Politics of Disposability. Boulder:Westview Press.

Grossberg, Lawrence. 1992. We Gotta Get Out of this Place. New York and London:Routledge.

Hall, Stuart and Jacques Martin, eds. 1983. The Politics of Thatcherism. London:Lawrence and Wishart.

Kellner, Douglas. 1990. Television and the Crisis of Democracy. Boulder:Westview Press.
1995. Media Culture. London and New York: Routledge.

-..-- 2001. Grand Theft 2000. Lanham, Md.:Rowman and Littlefield.

-.-- 2003a. Media Spectacle. London and New York:Routledge. -.--- 2003b. From 9/11 to Terror War: Dangers of the Bush Legacy. Lanham, Md.:Rowman and Littlefield.

----- 2005. Media Spectacle and the Crisis of Democracy. Boulder, Col.:Paradigm Press.

Kellner, Douglas and Michael Ryan 1988. Camera Politica: The Politics and Ideologies of Contemporary Hollywood Film. Bloomington:Indiana University Press. 